ISSN: 0213-2052 - eISSN: 2530-4100

DOI: https://doi.org/10.14201/shha202038245272

\title{
IMPERIAL ADJUDICATION IN LATE ANTIQUITY: EVOLUTIONS AND PERCEPTIONS IN THE LIGHT OF DOCUMENTARY EVIDENCE
}

\section{Adjudicaciones imperiales en la Antigüedad tardia: evoluciones y percepciones a la luz de las evidencias documentales}

\author{
Luisa ANDRIOLLO \\ Postdoctoral Researcher \\ Otto-Friedrich-Universität Bamberg
}

Fecha de Recepción: 28-2-2020; aceptación definitiva: 19-06-2020

ORCID: https://orcid.org/0000-0002-0700-1116

\begin{abstract}
This paper explores the functions of recorded proceedings in late antique court administration, focusing on documentary records related to imperial adjudication. Verbatim records of verdicts uttered by the emperor on individual cases are on the whole scarcely attested; they become particularly rare from the mid-3rd century $\mathrm{AD}$, and are no longer preserved after the 4th century. The author scrutinizes the causes and meaning of such a state of evidence. After an in-depth analysis of the extracts of proceedings included in the Theodosian and Justinian codes, parallel literary and non-literary sources on imperial jurisdiction in the 4th and 5th centuries are considered. The discussion highlights changes occurred in the function, circulation and reception of minuted records. These reflect evolutions which affected not only judicial procedure, but also the understanding of the imperial role, the forms of institutional communication, and late antique legal thinking.
\end{abstract}

Keywords: Imperial jurisdiction; late antique bureaucracy; records of proceedings; Theodosian Code; Justinian Code. 
RESUMEN: El estudio trata sobre los usos de los registros documentales por parte la administración palatina de la Antigüedad tardía centrándose en las actas relacionadas con la adjudicación imperial. En general, los registros documentales de veredictos pronunciados por el emperador apenas se han conservado; se vuelven especialmente raros a mediados del siglo III y ya no se conoce ninguno después del siglo iv. La autora analiza las causas y el significado de dicho estado de la documentación. Después de analizar los extractos de actas incluidos en los Códigos de Teodosio y de Justiniano se consideran fuentes paralelas, literarias y no literarias, acerca de la jurisdicción imperial en los siglos iv y v. La discusión destaca los cambios ocurridos en la función, circulación y recepción de los registros documentales. Estos cambios atestiguan las evoluciones que afectaron no solo el procedimiento judicial, sino también la visión de la función imperial, la comunicación institucional y el pensamiento jurídico.

Palabras clave: Jurisdicción imperial; burocracia de la Antigüedad tardía; registros documentales; Código Teodosiano; Código de Justiniano.

\section{ACKNOWLEDGEMENTS}

This article is part of a project that has received funding from the European Research Council (ERC) under the European Union's Horizon 2020 research and innovation programme under grant agreement No 677638. I thank Peter Ridlberger for reading a draft version of this paper and offering helpful advice. All remaining mistakes are my own.

\section{RECORDS OF PROCEEDINGS AND IMPERIAL JURISDICTION: STATE OF DOCUMENTATION}

It is generally acknowledged that the recourse to written documents and especially verbatim records of proceedings acquired growing importance and visibility during late antiquity. Minutes were regularly appealed to as proofs of procedural accuracy and juridical validity, notably in the context of ecclesiastical controversies ${ }^{1}$. This paper is part of a research aiming to assess the role played by the central imperial administration, particularly court bureaucracy, in this shift in attitude towards minuted records. Was this emerging trend in documentary habits anticipated, followed or resisted at the very heart of late Roman imperial power? The assumption underlying this discussion is that evolutions in bureaucratic

1. Harries 1999, 56-59; Graumann 2018. On the development of tachygraphy and Roman imperial bureaucracy see the classic study of TeitLer 1985 . 
AND PERCEPTIONS IN THE LIGHT OF DOCUMENTARY EVIDENCE

practices may betray changes in political culture and in the modes of rule, and contribute casting new light on them.

Documentary records of imperial oral pronouncements are of particular interest for this inquiry. Obviously, the emperor's words were not subject to contestation, nor could his decisions be appealed. This deprived records of imperial utterances of some basic functions performed by minutes in most judicial and polemical contexts ${ }^{2}$. However, other reasons justified their existence: in primis the need to keep track of pronouncements which had inherent normative value, and to enforce them ${ }^{3}$. Beside their specific juridical content, documents recording imperial oral pronouncements provide clues to the institutional visibility of Roman rulers and its impact on official communication. This paper will focus on the production and circulation of such texts in the field where we most expect to find them, that is, imperial jurisdiction.

The giving of justice was an essential constituent of the imperial function, and the emperor's main occupation in peacetime $e^{4}$. Historians and scholars of Roman law have investigated from a variety of perspectives the origins, legal foundations, and modus operandi of imperial jurisdiction up to the Severan age 5 . The attention devoted to the fate of imperial adjudication thereafter, instead, has been piecemeal ${ }^{6}$. An obvious reason for this is the shrinking of relevant sources, starting from the second half of the 3rd century.

Let us have a preliminary survey of documentary sources which appear to preserve verbatim records of cases debated before the emperor. If we consider their global number, varying features and diachronic distribution, some significant facts stand out. From the reign of Augustus to the beginning of the 6th century, the global volume of relevant attestations is remarkably reduced. This holds true even when we take into account not only imperial decreta or sententiae - i.e. verdicts on lawsuits pronounced by the ruler ex tribunale - but also oral decisions given out of court (interlocutiones de plano) and rulings uttered in consistorio, which

2. HARRIES 1999, 110.

3. As summarized by Ulpian's definition: Quodcumque igitur imperator per epistulam et subscriptionem statuit vel cognoscens decrevit vel de plano interlocutus est vel edicto praecepit, legem esse constat. Haec sunt quas vulgo constitutiones appellamus (Dig. 1.4.1).

4. Millar 1977, 507-537; Honoré 1994, 1-32; Peachin 1996, 79-88.

5. See n. 4 above, and Kelly 1957; Coriat 1997 and 2016; Wankerl 2009; Rizzi 2012; HURLET 2016.

6. The issue of the emperor's judicial competence is touched briefly by HaRRIEs 1999, 38-42, and Matthews 2000, 12-17. The subject is approached also in Pergami 2000, 440-462; DiLLON 2012; FärBER 2014, 67-122. 
can equally be regarded as expressions of the emperor's judicial capacity ${ }^{7}$. As pointed out by Tony Honoré, such oral pronouncements are generally underrepresented in juridical literature: only 4 imperial decreta are included in the Justinian Code, against 2609 private rescripts and 51 letters ${ }^{8}$. As we shall see, some extracts of imperial judgments can be found also in the Theodosian Code. If we add records of proceedings preserved in epigraphic, papyrological and manuscript sources other than legal codes, we would still gather less than 30 attestations?

The forms of circulation and transmission of these documents, and their variations over time are also significant. Up to the early 3rd century, documents recording lawsuits debated before Roman emperors are known through a small number of inscriptions and a larger amount of papyri; reports of imperial judicial decisions in the writings of the jurists might also have drawn on court records ${ }^{10}$. After the Severan age, no such document is preserved in epigraphic or papyrological sources. From this time onwards, all available evidence consists in a handful of extracts of proceedings included in the Theodosian and the Justinian Code ${ }^{11}$. The last known record of an orally delivered imperial decree is reported in Cod. Theod. 4.20 .3 and dated to 386.

The features of this documentation raise a number of questions. In the first place, we are faced with issues concerning the identification of relevant sources and their interpretation as verbatim records of judicial proceedings. In some cases, the fragmentary state of these documents and their brevity may indeed raise doubts as to whether they really recorded orally delivered pronouncements and actual imperial hearings. Under the Principate, the larger number and variety of available documents allow comparisons, getting insights into the judicial procedures and the editorial work associated with the production, copying and circulation of minutes. For later periods, the exclusive dependence on the work of the Theodosian and Justinian compilers, who deliberately reduced imperial constitutions

7. NÖRR 1983. CORIAT 1997, 98-99, considers imperial decisions pronounced de plano as decreta to all effects. According to Moreno Resano 2003, imperial interlocutiones were always judicial, as they were pronounced ex imperio and had the force of law.

8. HONORÉ 1994, 28.

9. I have counted 23 texts which seemingly reproduce records of judicial proceedings presided over by the emperor. One may wish to include in the discussion also sources of dubious interpretation, like the Severan apokrimata, the so-called Acta Alexandrinorum and the Hadriani sententiae. A global presentation of sources on imperial oral pronouncements is the subject of forthcoming study.

10. The interpretation of juridical writings and their possible documentary sources is a subject of debate: VolterRa 1971, 983-1001, and Rizzi 2012, 15-133.

11. Commented below. 
to their normative content, suppressing any additional details, makes it harder to reconstruct the circumstances and procedures behind imperial pronouncements. At any rate, the shrinking in number of sources and their ultimate disappearance at the end of the 4th century call for explanation. Is this state of our evidence an effect of editorial policies adopted by late antique compilers? Does it betray an evolution in the way records were made, circulated and used? Or does it point to substantial changes in the practice of imperial adjudication? To answer these questions, I will examine extracts of judicial proceedings from the 3rd and 4th centuries preserved in law codes. After discussing their content and form, I will contextualize them against the background of other sources referring to imperial jurisdiction in late antiquity, including imperial legislation and literary texts.

\section{EXTRACTS OF PROCEEDINGS AND IMPERIAL ADJUDICATION in the Theodosian and Justinian codes}

The earliest relevant passage is a pronouncement ascribed to Philip the Arab, reported in the Justinian Code (Cod. Iust. 7.26.6). The same code includes three verdicts dating back to the first Tetrarchy (Cod. Iust. 9.1.17, 9.47.12 and 10.48.2). Two rulings issued by Constantine the Great (Cod. Theod. 8.15.1 and 7.20.2) and one by Julian (Cod. Theod. 1.22.4) are preserved in the Theodosian Code. We have two more decisions attributed to the imperial collegium of Gratian, Valentinian II and Theodosius I (Cod. Theod. 1.22.4 and 11.39.8), and one to Theodosius I alone (Cod. Theod. 4.20.3). The identification of these passages as extracts of recorded proceedings is based on two distinctive elements: 1) the apparent inclusion of dialogues and speeches in direct form, involving the emperor and dealing with juridical problems; 2) references to the fact that these passages were drawn from imperial acta, typically included in the initial protocol.

\subsection{Content and case matter}

Only four of these texts, all dating from the rules of Diocletian and Constantine, explicitly refer to the presence of individuals and groups who act as interlocutors of the ruler. Records of Diocletianic pronouncements show that litigations could involve collectivities and specific categories of people; these texts suggest that imperial audiences could unfold - at least on some occasions - before a quite large audience, implying different degrees of publicity. Cod. Iust. 9.47.12, for instance, reports a statement 
attributed jointly to Diocletian and Maximianius, which protected the sons of decurions from any condemnation ad bestias.

Imp. Diocletianus et Maximianus AA. in consistorio dixerunt: Decurionum filii non debent bestiis subici. CUMQUe a POPULO EXCLAMATUM EST ITERUM DIXERUNT: Vanae voces populi non sunt audiendae: nec enim vocibus eorum credi oportet, quando aut obnoxium crimine absolvi aut innocentem condemnari desideraverint. SINE DIE ET CONSULE.

The Emperors Diocletian and Maximian Augusti said in the consistorium: "The sons of decurions must not be thrown to beasts." And since the people cried out, they added: «No attention should be given to the vain remonstrances of the populace; for it is not reasonable to lend credence to their clamours, when they wish a criminal to be freed, or an innocent to be condemned.» Without date and designation of consul ${ }^{12}$.

This imperial decision concerned the privileges of decurions' sons in relation to capital punishments. Here, an issue concerning criminal procedure and status prerogatives is said to be settled by the emperor in consistorio. This mention of the consistory has been regarded either as an anachronism to indicate the imperial consilium, or as an early reference to a space within the imperial residence where imperial jurisdiction was exercised ${ }^{13}$. At any rate, the attendance of a popular audience was not excluded, at least at the moment when the imperial verdict was announced: the text reports the protests of the populace in indirect form, as well as the imperial reply that no credit shall be given to such vanae voces. Tough the imperial statements, as reported in the code, express general principles of action, they likely originated from the examination of a specific case - possibly the reversal of a condemnation in appeal. On another occasion, the presence of a specific group of citizens, the principales from Antioch, is recorded along that of individual plaintiffs (Cod. Iust. 10.48.2):

Pars actorum Diocletiani et Maximiani AA. id. Febr. .... inductis Firmino et Apollinario et Ceteris principalibus Antiochensium adstantibus Sabinus dixit: ..... Diocletianus: Certis dignitatibus data a nobis indulgentia est munerum civilium et personalium, id est bis, qui aut ex protectoribus sunt aut ex praepositis. Ii ergo ad munera personalia aut civilia non vocabuntur.

Extracts from the acts of Diocletian and Maximian Augusti, on the Ides of February. [...] After Firminus and Apollinarius had been led in, and while the other principales of Antioch were standing by, Sabinus said: ... Diocle-

12. All translations, if not otherwise stated, are mine.

13. Corcoran 2000, 255-256; contra FärBer 2014, 79-80 and 100-101. 
tian (said): We have granted exemption from civic and personal services to specific dignities, that is, to those ranking among the protectores and praepositi. Therefore, they shall not be called to discharge personal or civic services.

There is no agreement about the exact nature of this audience. An imperial cognitio might have been solicited by some concerned individuals (the Firminus and Apollinarius named in the text?), to invalidate their nomination in the ordo decurionum and the resulting imposition of munera, in first instance or appeal ${ }^{14}$. Alternatively, their reclamations might have been heard by Diocletian in the context of an administrative (and not properly judicial) procedure; in this case, the Antiochene principales would act as an interested audience, not as opponents in a lawsuit ${ }^{15}$.

Constantine the Great also granted audiences to both groups and individuals. The imperial audience recorded in Cod. Theod 7.20.2 takes place in a legionary camp, with the participation of military officers, a group of veterans soliciting fiscal privileges, and their spokesman Victorinus ${ }^{16}$. In Cod. Theod. 8.15.1 a woman named Agrippina protests the lawfulness of a purchase made by herself and one Codia against the claims of the imperial fiscus ${ }^{17}$. The protocol frame is completely lost; only the dialogue between Constantine and Agrippina is preserved:

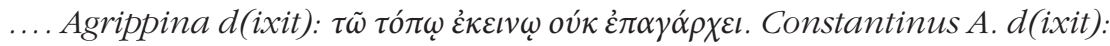
Sed iure continetur, ne quis in administratione constitutus aliquid compararet, unde quidem nibil interest, an in suo pago an in alieno comparavit, cum constet contra ius eundem comparasse. Et adiecit: ignoratis fiscale affici totum, quidquid administrantes comparaverint? Agrippina dixit: $\tau$ ṽ

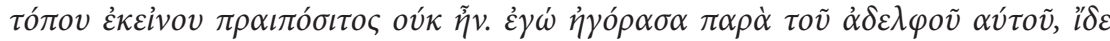

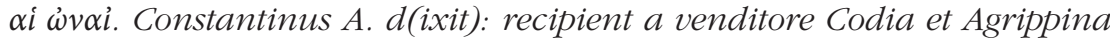
competens pretium.

.... Agrippina said: «He was not pagarch in that district». Constantine Augustus said: «But it is established by law that nobody holding an office in the public administration shall purchase anything. Hence it makes no difference whether he purchased it in his own district (pagus) or in the district of another, since it is obvious that he made the purchase against the law." And he added: "Do you not know that whatever administrators

14. Corcoran 2000, 254-255.

15. BIANCHINI 1975, particularly 342 .

16. The location and date of events are debated: Barnes 1982, 69, n. 102; CorCoran 2000, 257-259; ConNolly 2010, 96-97. English translation and commentary in ANDRIOLLO 2018, 84-90.

17. Bianchini 1984; Corcoran 2000, 259-260 and 2006, 41-42. Surprisingly, MatTHews 2000, 16 n. 14 and 172, considers this text the copy of a private rescript. 
purchase is made the property of the fiscus?» Agrippina said: «He was not the praepositus of that district. I made the purchase from his brother. Here is the deed of sale.» Constantinus Augustus said: "Codia and Agrippina shall recover the legal price from the vendor.»

In other cases, the text reported in the codes does not include any dialogic interaction. However, what remains of the protocol hints at discussions which preceded the imperial decision, or at the oral delivery of the latter. This seems to be the case for Cod. Iust. 7.26.6:

Imp. Philippus A. Cum Consilio Collocutus Dixit: Cum sit probatum rem pignori fuisse obligatam et postea a debitore distractam, palam est non potuisse eam quasi furtivam usucapi. SINE DIE ET CONSULE

Philip Augustus, after discussing with the council, said: «Since it has been proven that the property was pledged and afterwards sold by the debtor, it is clear that, being, as it were, stolen, it cannot be acquired by usucaption." Without date and designation of consul.

Here, the concerned parties are not named, and the verdict issued by Philip the Arab is introduced in as general terms as possible. Yet, references to the deliberative process and to proofs of an invalid sale suggest that the Philip's pronouncement addressed a specific case discussed in the imperial council. This could be a final judgment pronounced at the end of an imperial cognitio. Cod. Iust. 9.1.17 reports the extract of a sentence formally ascribed to Diocletian and Maximian:

Pars sententiae eorundem AA. et CC. Datae v id. Ian. Diocletiano vit et MaxiMIANO VI AA. CONSS. Iniquum et longe a beatitudine saeculi nostri esse credidimus, ut Thaumastus accusandi eius haberet facultatem, in cuius domo eum, licet ingenuum, a prima tamen aetate fuisse constabit. Quare ex nomine Thaumasti mentio super conflictu criminali Symmacho conquiescat. Si quam sane civilem petitionem idem Thaumastus sibi competere confidit, iudicio praesidiali poterit experiri.

Extract of the sentence of the same Augusti and Caesars, given on the fifth day before the Ides of January, under the consulship of the Augusti Diocletian, for the seventh time, and Maximian, for the sixth time [9 January 299]. We have considered it unjust and far from consonant with the felicity of Our era that Thaumastus shall have the possibility to accuse the man in whose house, notwithstanding being freeborn, he demonstrably lived from his infancy. Therefore, any criminal prosecution against Symmachus on the part of Thaumastus shall stop. If, however, said Thaumastus believes that he has any grounds for a civil action, he can turn to the governor of the province for judgement. 
The Augusti deliver a partial verdict on the admissibility of a lawsuit: they definitely deny the right of one Thaumastus to bring a criminal charge against Symmachus, but they allow him to initiate a civil action before the provincial governor. We do not know whether the case had been referred to the emperor by a lower judge for consultation and preliminary assessment, or if Symmachus had appealed to the imperial tribunal. The wording of the sententia, with the rhetorical appeal to equity as a guiding principle of imperial action, would fit well an originally written statement. ${ }^{18}$ This, however, does not rule out the possibility that the parties were present at the moment when the judgment was pronounced or rather read out by the emperor. ${ }^{19}$

Later constitutions are more laconic. Texts from the second half of the 4 th century are almost invariably labelled pars actorum, with the specification that the discussions recorded took place in consistorio: the consistory of Julian in Constantinople in Cod. Theod. 11.39.5, of Gratian in Cod. Theod. 1.22.4 and of Theodosius I in Cod. Theod. 11.39. 8. Only Cod. Theod. 4.20.3 presents a variation in the opening formula: Emperor Theodosius I is said to have pronounced a statement apud acta. Cod. Theod. 11.39 .5 mentions some of the members of Julian's consistory by name:

Pars actorum habitorum aput imperatorem Iulianum Augustum Mamertino et Nevitta conss. X Kal. April. Constan(tino)p(oli) in consistorio: adstante Iovio Viro Clarissimo quaestore, Anatolio magistro officior(um), Felice com(ite)

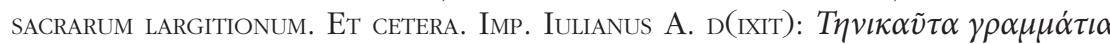

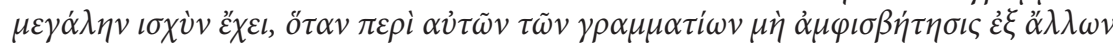
ó $\varepsilon \dot{\imath} \lambda \varepsilon \iota \beta \varepsilon \beta \alpha \iota$ ṽ $\sigma \alpha$ l.

Part of the proceedings held before the emperor Julian Augustus, under the consulship of Mamertinus and Nevitta, on the tenth day before the kalends of April at Constantinople, in the consistory [23 March 362]. In the presence of the quaestor Jovius, vir clarissimus, Anatolio, master of the offices, and Felix, count of the sacred largesses. After other things. Emperor Julian Augustus said: "Written instruments [only] possess great force as long as there is not some doubt regarding these written instruments which requires support from other (written proofs).»

Elsewhere the consistory is evoked only in general terms, as the setting for imperial pronouncements, with no specific information about its composition. Here are the concerned passages:

18. Corcoran 2000, 257.

19. Cod. Theod. 11. 30.40 (a. 383): a sentence, to be considered a final one, had to be read from a written tablet. The practice was in already use in Severan times, as attested by P.Oxy. LI 3614 (judgment pronounced by Septimius Severus: below, 255, n. 23) 
Cod. Theod. 1.22.4: Imppp. Grat(ianus), Valent(inianus) et Theod(osius) aAAA. Pars actorum habitorum in consistorio Gratiani A. Gratianus A. Dixit: Det operam iudex, ut praetorium suum ipse conponat. Ceterum neque comiti neque rectori provinciae plus aliquid praestabitur, quam nos concessimus in annonis seu cellariis. Et cetera. Actum IN CONSistorio Merobaude II et SATURnino vv. cc. conss.

Emperors Gratian, Valentinian and Theodosius Augusti. Part of the proceedings held in the consistory of Gratian Augustus. Gratian Augustus said: "The iudex [here: probably praetorian prefect] shall take care of providing supplies for his praetorium. Furthermore, neither to a comes nor to a rector [governor] of a province will be provided anything more than what we granted in subsistence allowances (annona) and cellar provisions.» And other things. Done in the consistory under the second consulship of Merobaude and in the consulship of Saturninus, viri clarissimi [383].

Cod. Theod. 11.39 .8 (= Cod. I ust. 1.3.7): PARS ACTORUM Habitorum IN CONsistorio aput imperatores Gratianum, Valentinianum et Theodosium cons. Syagri et Eucheri die III Kal. iul. Constantinop(oli). in consistorio imp. Theod(osius) A. D(IXIT): episcopus nec bonore nec legibus ad testimonium flagitatur. IDEM DIXIT: episcopum ad testimonium dicendum admitti non decet, nam et persona debonoratur et dignitas sacerdotis excepta confunditur.

Part of the proceedings held in the consistory, before the emperors Gratian, Valentinian and Theodosius. Under the consulship of Syagrius and Eucherius, on the third day before the kalends of July in Constantinople [29 June 381]. The emperor Theodosius Augustus said in the consistory: "A bishop is not required either by honour or by law to act as witness.» The same (emperor) said: «It is not fitting for a bishop to be admitted to give testimony: indeed, his person is dishonoured thereby and the privileged dignity of episcopacy is demeaned."

Cod. Theod. 4.20.3: Apud acta Imp. Theod(osius) A. D(Ixit): In omni cessione professio sola quaerenda est. Idem d(ixit): In omni cessione sufficit voluntatis sola professio. Dat. Kal. Mai. Honor(io) n. p. et Evodio coss.

Emperor Theodosius Augustus declared for the official record: «In every cession of goods a public declaration alone shall be required.» The same (emperor) said: «In every cession of goods the declaration of intent alone is sufficient.» Given on the kalends of May, under the consulship of emperor designate Honorius and Evodius [1 May 386].

The tendency to extract from a particular imperial decree a general normative principle, recasting it in the form of a self-sufficient constitution is especially conspicuous in these texts. Julian's and Theodosius I's decisions concern issues of court procedure: the validity of written instruments ( $ү \rho \alpha \mu \alpha \dot{\alpha} \tau \iota)$ in lawsuits (Cod. Theod. 11.39.5) and the testimony of bishops (Cod. Theod. $11.39 .8=$ Cod . Iust. 1.3.7). Gratian stated on the allocation 
of provisions to provincial governors ( $\mathrm{Cod}$. Theod. 1.22.4). Theodosius I clarified what acts were required for a cession of goods to be valid (Cod. Theod. 4.20. 3). Though these rulings probably stemmed from the discussion of individual cases, their formulation glosses over the circumstances under which these were brought to the attention of the ruler. No internal hint permits to know whether appellants were allowed to plead their cause in the consistory, or cases were discussed behind closed doors, on the basis of written documents and reports made by delegate officers. ${ }^{20}$ It cannot even be excluded that fragments of the acta consistorii included in the codes reported imperial pronouncements elicited by means of written queries and petitions sent by provincial magistrates and private individuals respectively. ${ }^{21}$ Some of these requests could be examined in the consistory, and imperial statements on such matters could be recorded as interlocutiones in the acts of the consistory's sessions. The latter may have served as preparatory notes for the elaboration of official replies. It has also been suggested that extracts of the consistory records could be forwarded to officials as complements to imperial letters and official instructions. ${ }^{22}$ As an alternative, the passages considered might refer to the final validation in the consistory of decisions previously debated and agreed upon, through their reading by the emperor: this action might have been recorded apud acta in the form of a normative oral pronouncement. ${ }^{23}$

\subsection{Procedure and circulation of records}

A certain diversity in the nature of the cases addressed and, accordingly, in the procedures applied is discernible. Several fields of jurisdiction are represented: private law, particularly regulations concerning the acquisition and alienation of property, as well as administrative and procedural

20. See Cod. Theod. 12.12 .10 (a. 385) on the hearing of provincial delegations by the praetorian prefect, who would report claims to the emperor. A final decision was to be reached by the ruler in the consistory.

21. HaRries 1999, 47-53; Dillon 2012, 196-213.

22. Riedlberger 2020, 210-211. If the data mention is a mark of emission, as argued by ID. 2020, 247, its presence in Cod. Theod. 4.20 .3 would confirm that copies of minutes were sent out as items of official correspondence.

23. Cf. Cod. Iust. 1.14.8 (a. 446) and Honoré 1998, 13-14. The passages examined present the verb dixit, not recitavit; however, other sources show that the reading of a written provision may be introduced by a verb of speaking: see ANDRIOLLO 2018 on Cod.

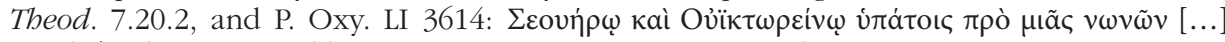

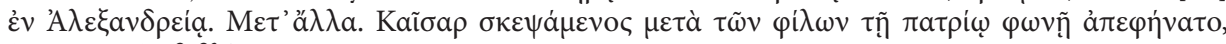

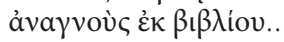


law. The sources examined do not provide unequivocal indications with respect to the stage of the lawsuit engaged (first instance or appeal) and the typology of decision reported (final, partial or interlocutory decision). ${ }^{24}$ On the whole, the nature of our evidence makes it problematic to pinpoint neatly defined and mutually exclusive procedural models. What emerges is rather a certain adaptability and permeability of judicial and administrative proceedings. The fact that imperial audiences might be interpreted either as appeal hearings or non-judicial actions (as in Cod. Iust. 10.48.2) is indicative of procedural proximity and the wide-reaching character of imperial jurisdiction. The interpretation of all the pronouncements we have considered as interlocutiones of different genre, advanced by Esteban Moreno Resano, reflects this fundamental elusiveness. ${ }^{25} \mathrm{I}$ would not exclude that at least some records inserted in the codes referred to actual imperial $\operatorname{cog}$ nitiones; however, the possible relation between interlocutiones de plano and alternative procedures, such as the submission of libelli, needs to be taken into account. ${ }^{26}$ When prominent individuals or communities were involved, the delivery of petitions could unfold during imperial audiences; on these occasions, the response of the emperor was announced orally and stenographic records of proceedings were most likely produced. We also need to envisage the possibility that some of these excerpts recorded debates or deliberations preceding not only the utterance of an imperial sentence, but also the elaboration of written responses to consultationes and libelli in the consistory.

At any rate, the absence of reference to petitioners and appellants in records of imperial decisions dating from the second half of the fourth century is striking. Is this just the product of abbreviations and editing? Or are we faced with a mediated and written form of appeal - an appeal more consultationis -, which made unnecessary the presence of the parties and the personal involvement of the ruler ${ }^{27}$ The sources analyzed tend to contradict the idea of a complete withdrawal of Roman rulers from the active giving of justice. Nevertheless, the emperor's face-to-face interaction with subjects becomes less and less visible as we move towards the end of the period considered. Another striking feature of our documentation is the tendency toward an increasing formalization and standardization, both in

24. The problem is recurrent in early imperial juridical sources: CORIAT 1997, 284-307; Wankerl 2009, 227-233, and the review by Mantovani 2015; Rizzi 2012, 415-422.

25. Moreno Resano 2003 and 2008.

26. Suggested by NÖrR 1983, 528-529, and MOREno Resano 2003.

27. Pergami 2000, 447-448; Dillon 2012, 216-250; Färber 2014, 108. See also below, 262-263. 
the opening protocol and in the body of the text, more conspicuous as we move towards the late 4 th century. ${ }^{28}$

Until the age of Constantine, and in part still in the 360s, excerpts of recorded proceedings, as they are transmitted in legal codes, present a notable formal variety. At the same time, these texts show similarities with earlier records of imperial judgements preserved in inscriptions, papyri and legal texts. As we have seen, the pronouncements reported in Cod. Iust. 7.26.6 and 9.1.17 consist of the sole quotation of imperial provisions, without any dialogue. This formulation is reminiscent of imperial decrees (apophaseis, apokrimata) copied in Egyptian papyri of the Antonine and Severan age, such as Hadrian's apophasis quoted in P. Tebt. II 286, ${ }^{29}$ and the famous Severan apokrimata collected in Pap. Col. $123 .{ }^{30}$ Both late antique constitutions and earlier papyrological records offer examples of the brachylogy and ambiguous relationship between orality and written words that characterizes many Roman legal texts and complicates procedural interpretations. The structure of the intitulatio in Cod. Iust. 7.26.6 - a participial sentence followed by the verb of speaking (cum consilio collocutus dixit) - is repeated with variations in the protocol of other records from Tetrarchic and Constantinian times. Introductory formulas in Cod. Iust. 10.48.2, Cod. Theod. 7.20.2 and Cod. Theod. 11.39.5 also find parallels in the opening clauses of earlier documents: the famous Dmeir inscription, which records a hearing presided over by the Caracalla, ${ }^{31}$ and an interlocutio of the same emperor preserved in Cod. Iust. 9.51.1.32 Variations in the circumstantial details provided by the initial protocol are not the only responsible for the apparent heterogeneity of imperial decreta from this period. The inclusion of non-imperial utterances, in the indirect or (more often) direct form, and statements in Greek (Cod. Iust. 10.48.2; Cod. Theod. 8.15.1 and 11.39.5) also contribute to this impression. The recourse of direct speech and bilingualism, too, fit in the patterns of

28. Connolly 2010, 112-113.

29. FIRA III, 100.

30. P. Col. 123, ed. Westermann and Schiller 1954, with integrations by Youthie and SchiLler 1955. The bibliography on Severan apokrimata is extensive: a recent clarification in HAENSCH 2007.

31. SEG XVII 759: Sabino et Anulino cos., VI Kalendas Iunias, Antiochiae, Imperator Caesar M. Aurelius Antoninus Pius Felix Augustus Parthicus maximus, Britannicus maximus, Germanicus maximus cum salutatus a praefectis praetorio eminentissimis viris, item amicis et principibus officiorum sedisset in auditorio, admitti iussit..

32. Imp. Antoninus Augustus cum salutatus ab Oclatinio Advento et Opellio Macrino praefectis praetorio clarissimis viris, item amicis et principalibus officiorum et utriusque ordinis viris et processisset, oblatus est ei Iulianus Licinianus.. 
judicial minutes transmitted by earlier documentary papyri, ${ }^{33}$ and the inscription of Dmeir. Quite differently, constitutions dating from the 380s are regularly introduced by a standardized and synthetic extract-formula (pars actorum habitorum in consistorio; on one occasion apud acta), followed by the mention of the emperor responsible for the ruling and, in some cases, date and place; then come the usual construction "name of the emperor + dixit and the normative provision. For all these pronouncements a dating is preserved. How shall we explain the formal variety of Tetrarchic and Constantinian constitutions, and the apparent turn in style of the late 4th century?

One could first consider the role played by the Theodosian and Justinian compilers in the arrangement of the text as it is transmitted. The analysis carried out by John Matthews on the text of the Theodosian Code has shown that editorial interventions were usually confined to (quite drastic) abbreviations, while other amendments were limited in scope. ${ }^{34}$ Justinian commissioners enjoyed larger editorial freedom; however, a comparison between imperial decreta repeated in both codes suggests that they tended to respect the wording of imperial utterances, though cuts and alteration of the words order could occur. ${ }^{35}$ The heterogeneity observed, then, is likely to be intrinsic to the documents that the compilers collected and excerpted. There is no need to revive here the thorny question of the sources of the Theodosian and Justinian codes. It will be enough to remind that imperial constitutions were retrieved from a variety of sources, among which provincial archives and private collections played an important role, at least until the mid-4th century. ${ }^{36}$ Documents

33. Coles 1966, 13-38 and passim; STOlte 2003, 265-266.

34. Matthews 2000, 55-64, 277-279; SirKs 2007, 54-68. In the texts analysed, shortening and omissions are signaled by the labels pars actorum/pars sententiae and the annotation et cetera. The reiteration of imperial statements (et adiecit/idem dixit: Cod. Theod. 8.15.1, $4.20 .3,11.39 .8$ ) might point to replies or deliberative pauses suppressed by the editors.

35. Cod. Theod. $11.39 .8=$ Cod. Iust. 1.3.7: in consistorio/in sacro consistorio; cons Syagri et Eucheri/ cons. Syagri et Eucheri virorum clarissimorum; in consistorio Imp. Theodosius A. dixit/Imp. Theodosius A. dixit; episcopus nec honore nec legibus ad testimonium flagitatur/ nec honore nec legibus episcopus ad testimonium flagitatur; persona debonoratur/persona oneratur. In Cod. Theod. 7.20.2 = Cod. Iust. 12.46.1 the veterans' acclamation is christianized: dii te nobis servent/deus te nobis servet. The text of Constantine's provision in favour of the veterans presents discrepancies in the two versions, but this section is corrupted at several points (ANDRIOLLo [2018], 89-90). On the work of the Justinian compilers: Gaudemet 1979, 52; Delmaire 2012; Riedlberger 2020, 169-171.

36. Honoré 1998, 137-139; MatThews 2000, 282-289; Sirks 2007, 125. On pre-Tetrarchic and Tetrarchic constitutions, CORCORAN 2000, 25-38. 
dating from the late 4th century onwards, instead, have higher chances to come from the central imperial archives. ${ }^{37}$

Inscriptions and papyri indicate that in early imperial times records of proceedings held before the emperor were copied and circulated in the provinces, notably in conjunction with imperial visits; in some cases, the imperial commentarii are indicated as the source for local copies. ${ }^{38}$ These were not the only documents drafted and delivered on the occasion of imperial cognitiones. A passage in the Digest reports a verdict uttered by Marcus Aurelius in the presence of the parties and refers to a rescript on the same case issued contextually. ${ }^{39}$ Copies of minutes recording imperial hearings were delivered upon request by the central administration to appellants and petitioners. In keeping or inscribing such records, their recipients must have been prompted not only by the willingness to ensure the lasting knowledge of imperial rulings, but also by the wish to preserve the memory of an event perceived as an exceptional source of pride. ${ }^{40}$

The conditions for a relative accessibility of these documents might have lasted into the first half of the 4th century. Similarities in form and content between extracts of proceedings included in late ancient codes and earlier records of imperial hearings point to similar patterns of circulation and transmission. Texts from the late 3rd and early 4th centuries continue to show the emperor interacting with his subjects. The emperor's interlocutors, individuals or groups, as well as the magistrates in charge of executing his decisions might have requested and obtained copies of these minutes, which were kept as reminders of the imperial intervention, proofs of the rights established and guidelines for future action. The phrasing of these texts, their lack of uniformity and their possible lacunae may reflect their "prehistory of transmission ${ }^{41}$ and, with it, the interests and editorial activity of their first recipients and users.

This situation appears to change during the second half of the 4th century. Extracts of proceedings from this period included in the codes

37. Honoré 1998, 137-141; Matthews 2000, 288-289; SiRKs 2007, 130-137.

38. Apart from the Severan papyri and the inscription of Dmeir (above, 257, n. 31), see also a Latin inscription from Ainos, dated to the joint rule of Caracalla and Geta: Kaygusuz 1987, 66; Mourgues 1998, 138-139 and 162-163.

39. Dig. 28.4.3: Antoninus Caesar remotis omnibus cum deliberasset et admitti rursus eodem iussisset, dixit: "Causa praesens admittere videtur humaniorem interpretationem, ut ea dumtaxat existimemus nepotem irrita esse voluisse, quae induxit." Nomen servi, quem liberum esse iusserat, induxit. Antoninus rescripsit liberum eum nibilo minus fore: quod videlicet favore constituit libertatis. Commentary in WANKERL 2009, 68-94, and RIZZI 2012, 151-174.

40. STOLTE 2003, 267-268.

41. Matthews 2000, 287. 
are systematically dated and presented as excerpts from the acts of the imperial consistory, sometimes with the specification that meetings were held in Constantinople (Cod. Theod. 11.39 .5 and 11.39.8). The only utterances reported are now those of the ruler. While evolutions in procedure may account in part for these features, the formal standardization observable in the protocol and body of these texts could betray the work of an increasingly organized and professionalized palatine bureaucracy, which filed, edited and archived records in view of bureaucratic uses. This did not exclude textual manipulations and re-elaborations. In the 6th century, John Lydus wrote that, in addition to minutes, summaries of cases were compiled in Latin for prefectural archives. ${ }^{42}$ Perhaps abridged records of consistory sessions and imperial decisions were prepared, too, and used when fuller versions were not available or not suited for the task. While these documents (or extracts of them) could have circulated among imperial officials ${ }^{43}$ there is no evidence that copies of the consistory's acts were issued to private individuals. ${ }^{44}$

\section{ReCORDS OF PROCEEDINGS IN CONTEXT: PARALLEL SOURCES}

ON LATE ANTIQUE IMPERIAL JURISDICTION

The analysis carried out so far apparently points to a progressive reduction, in the course of the 4th century, of both the ruler's approachability and the accessibility of documents related to imperial adjudication. In order to substantiate this impression and appreciate its significance it is worth placing the documents considered within the context of other sources informing us about the fate of imperial adjudication between the 3 rd and the 6th century.

A need to filter the cases brought before the emperor had emerged since quite an early date. Documentary sources suggest that already in the 2nd century emperors and provincial governors faced an ever-increasing amount of judicial and administrative requests; as a result, they began to delegate business or deal with it in a hasty manner. ${ }^{45}$ Under the Severans, consular magistrates were appointed to judge vice Caesaris. Meanwhile, the development of the bureaucratic apparatus facilitated the indirect approach of the ruler for a number of officials and citizens, by means of

42. Lydus, Mag. 3.20 (ed. Schamp 2006, 68-69).

43. See above 255 , n. 22.

44. Castello 2018, 304-309.

45. HAENSCH 2008. 
written consultations and petitions ${ }^{46}$ Few people had the means to travel to the imperial court and, once there, obtain a personal audience; it was certainly more feasible to solicit an imperial rescript, even though petitions needed to be submitted personally (presumably to the office a libellis) by the petitioners or their delegates. A far larger number of cases must have been treated through this time-saving indirect procedure. This accounts in part for the disproportion in the number of attestations between records of imperial sentences and imperial rescripts.

In the field of delegate adjudication, a hierarchy of competences emerged during the 4th century: appellate jurisdiction for particular affairs was durably assigned to specific magistrates, such as the fiscal comites in financial matters. ${ }^{47}$ By the mid- 4 th century, the praetorian prefects were permanently invested with the jurisdiction vice sacra, and their verdicts were declared unappealable. ${ }^{48} \mathrm{~A}$ law of 440 , issued in the name of Theodosius II and Valentinian III, established that only appeals against the decisions of magistrates illustres could be submitted for imperial examination. ${ }^{49}$ Under Justin I, also these cases were referred to the quaestor sacri palatii, assisted by two imperially appointed judges..$^{50}$ In 529 , Justinian reintroduced imperial jurisdiction on appeals depending on value: the competence of the imperial tribunal was limited to cases worth over 20 pounds of gold. ${ }^{51}$ In a later novel (Nov. 2, a. 535) Justinian acknowledged that his legislation was to a large extent generated in response to "matters submitted to us by petitioners, and sometimes judicial proceedings. ${ }^{52}$

Normative texts indicate that access to imperial adjudication was certainly restricted in the course of time, but they also suggest that this possibility was rarely completely precluded. The emperor's engagement with jurisdiction could vary greatly, depending on individual abilities and inclinations. The extracts of proceedings that we have examined show that hearings in the presence of the ruler were held at least until the reign of Constantine. Literary sources complete this picture: energetic rulers like

46. Peachin 1996, 90-91 and 185-187; Coriat 1997, 304-307; Tuori 2016, 253-266. On the consultation and petition process under the Principate, Honoré 1994, 43-48, and Corcoran 2000, 43-48.

47. Cod. Theod. 11.30.18, 11.30.39, 11.30.45, 11.30.49; Butr 1982, 41-42, and 55; Pergami 2000, 422-425 and 440-447.

48. Cod. Theod. 11. 30.6, 11.30.16-17, 11.30.30, 11.30.40, 11.30.50. Harries 1999, 111112; Pergami 2000, 62-84, 125-126, 155-165.

49. Cod. Iust. 7.62.32.

50. Cod. Iust. 7.62.34

51. Cod. Iust. 7.62.37.

52. Transl. Miller and SarRis (2018), 66. 
Julian and Valentinian I still acted as judges in the 360s, "whenever the importance of the cases or of the persons required" it..$^{53}$ In the late 4 th and early 5th centuries, the prolonged minority of legitimate emperors must have hindered their active performance of judicial functions. ${ }^{54}$ John Lydus, however, recalls that in the time of Arcadius imperial secretaries were employed to record the lawsuits heard by the emperor with the assistance of senators. ${ }^{55}$ Sometime later, in the mid-5th century, a novel of Marcian reports the decision on a contested will in favour of a clergyman; the testament is said to have been examined and validated by the emperor in the presence of the senate (amplissimo senatu praesente). ${ }^{56}$ Doubts remain as to whether the concerned parties were present on such occasions. Perhaps both procedures - in the presence of the parties or through the sole examination of written documents - were possible, depending on circumstances. A law of Justin, mentioned earlier, would support this hypothesis, at least for the early 6th century: the quaestor and judges appointed by the emperor were required to examine appeals on the basis of a written relatio, sive praesentibus partibus... sive absentibus (Cod. Iust. 7.62.34). For the second half of the 5th century, the Chronicon paschale reports episodes of summary judgments held in the Hippodrome in the presence of the emperor, and appeals to the ruler made in the same place. ${ }^{57}$ In 465 , the prefect of the Watch Menas, «being accused of evil deeds, was questioned in the Hippodrome by the senate» and finally lynched by the crowd, with the approval of Leo I, who apparently assisted

53. Amm. Marc. 18.1.2 [transl. Rolfe 1950, 405]. Ammianus repeatedly presents Julian in the act of trying cases: Amm. Marc. 18. 1. 2-4, 22.7. 1-3, 22.9.8-11, 22.10.1-5. John Malalas and the Chronicon paschale recount the condemnation of the praepositus Rhodianus by Valentinian I in the Hippodrome (ca. 369): Ioh. Mal., 339-340; Chron. pasch., 558-559. Full survey of literary sources in FärBER 2014, 108-110.

54. McEvor 2013, 114-117 and 239-244.

55. Mag. 3.10 (ed. Schamp 2006, 55-56): vó

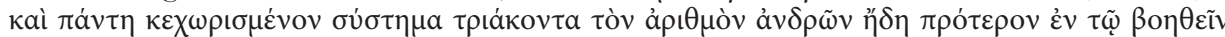

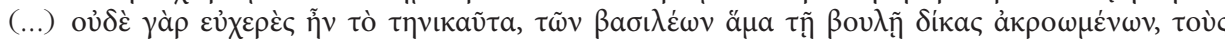

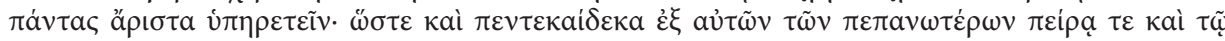

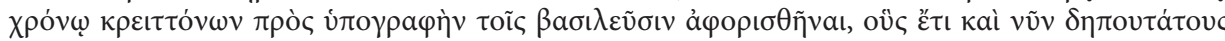

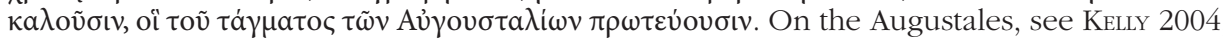
91-94. According to Pergami 2000, 438-439, the term $\beta$ ou $\lambda \dot{n}$ does not indicate the senate here but the consistory, which could include senators present in Constantinople.

56. Marc. Nov. 5, a. 455: Nuper cum de testamento clarissimae memoriae feminae Hypatiae, quae inter alios virum religiosum Anatolium presbyterum in portione manifesta bonorum suorum scripsit heredem, amplissimo senatu praesente tractaret pietas mea... universum testamentum iussimus relegi atque replicari.

57. On the presentation of petitions and appeals in the circus and Hippodrome: Cameron 1976, 162-173. 
to the event. ${ }^{58}$ Some thirty-five years later, "while chariot-races were being held, those of the faction of the Greens appealed to the emperor Anastasius that certain men be released who had been detained by the city prefect for stone-throwing»; Anastasius' intransigent refusal to hear popular requests resulted in a mass riot. ${ }^{59}$

It does seem, then, that late Roman emperors never completely ceased to have a say in the settlement of judicial and administrative cases, when the issue at stake, the circumstances or the status of the appellant made their intervention desirable. While routine appellate jurisdiction could be delegated to a plurality of officials, the emperor kept for himself the possibility to engage in actions invested with exemplary value ${ }^{60}$ What sources highlight is, as observed by Färber, a tendency to relocate the exercise of imperial jurisdiction from open civic spaces to the indoor dimension of the imperial residence and the consistory. ${ }^{61}$ As we have seen, this process appears to undergo an acceleration after the reign of Constantine the Great; in the late 4th century it mirrors the growing importance of court life and palatine officials for the shaping of imperial policy. In the East, this evolution coincides with the rise of Constantinople as the new political center of the Empire. ${ }^{62}$ Here, the sedentarization of the court and the development of an organized civic life also fostered the emergence of alternative settings for the display of imperial justice: the meetings of the senate and the Hippodrome. This revival of spaces and modes of political interaction reminiscent of the Principate is apparent in sources from the end of the 4th century. It responded to a renewed need of publicity and ceremonial communication between the court and the organized civic bodies of the City, and entailed a redefinition and new formalization of institutional and political relationships. ${ }^{63}$

The spatial evolutions we have outlined reveal the emergence of different strategic interlocutors of the imperial power over time. Peripatetic emperors like Diocletian and Constantine, who had to deal with military campaigns, civil wars and the pacification of reconquered territories, were

58. Chron. pasch., 594 (transl. M. and M. WhitBy 1989, 87). See also the case of Rhodianus above n. 52 .

59. Chron. pasch., 608 (transl. M. and M. WhiтBy 1989, 99). According to Michael and Mary Whitby, these events probably took place between 497 and 507.

60. FärBER 2014, 118.

61. FÄRBER 2014, 121-122.

62. Millar 2006, 193-201.

63. On the consistory and the Constantinopolitan senate under Theodosius II (408450), Millar 2006, 201-207. On the Hippodrome as the scenery for public interaction between emperors and different social and political actors: CAMERON 1976, 230-270. 
more prone to taking a personal interest in the requests of soldiers and urban aristocracies, and to engaging in occasional face-to-face interactions with them. Later emperors, when acting as adjudicators, were confronted to other power-players, such as imperial administrators (the iudices, comites and rectores addressed in Cod. Theod. 1.22.4) and churchmen (Cod. Theod. 11.39.8 and Marc. Nov. 5). No coincidence, the rare verbatim records of imperial utterances produced after the end of the 4th century are related to the spaces for public communication which emerged in this period, and to the forms of interactions between emperors and institutional interlocutors or organized social bodies which had developed therein. Among these texts are the protocols of imperial accessions collected by Petros, patrikios and magister officiorum under Justinian (later incorporated in the $10^{\text {th }}$-century Book of ceremonies), ${ }^{64}$ and conciliar acts which record imperial interventions in ecclesiastical controversies. ${ }^{65}$ These sources attest to the increasingly exemplar and ceremonial (not to say theatrical) connotation of imperial public appearances. On these occasions the emperor's role as an adjudicator is either absent or performed in relation to issues which involved the stability of public institutions rather than individual interests. In particular, religious dissent and ecclesiastical controversies opened up a new field of jurisdiction where imperial intervention was insistently solicited. ${ }^{66}$ Arbitration in ecclesiastical affairs granted the action of Roman emperors wide impact and visibility, as it affected beliefs, loyalties and public behaviours throughout the empire and it was amplified, for good or bad, by the preaching of clergymen and monks.

\section{INSTITUTIONAL CHANGES AND EVOLUTIONS OF DOCUMENTARY HABITS}

The observed shift towards administrative mediation and formalization and the prioritized treatment of cases affecting the interests of strategic social groups had an impact on the production and transmission of records relating to imperial jurisdiction. As we have seen, the features of the extracts of proceedings included in the codes hint at different types of sources available to the compilers, and their different degrees of accessibility and dissemination beyond court archives. As we move towards the end of the 4th century, the apparent standardization of these texts

64. De Cer. I, 91-93.

65. See, for instance, the acts of the sixth session at Chalcedon (451): ed. SchWARTZ, ACO 2.1, 327-354; ACO 2.2, 397-349.

66. Dvornik 1951; Drake 2015. 
betrays a closer connection with the palace and the work of a palatine bureaucracy responsible for the filing, archival and selective circulation of records. The fact that this type of imperial pronouncements is not quoted for the period after 386 prompts to consider the motives behind their selective inclusion in the Theodosian and Justinian codes and their ultimate neglect as a source of imperial law. At first sight, the incorporation of judicial decisions concerning individual cases defied indeed the criterion of generalitas, which was laid down in the course of the 5th century as a general principle of legislative action, and a specific requirement for legal texts to be included in the Theodosian Code. ${ }^{67}$

As we have seen, minutes of imperial judgments were probably not regarded as self-standing official texts, but rather as preparatory or complementary records associated with the issuing of other documents (imperial letters, private rescripts...). ${ }^{68}$ Throughout the period considered, their primary function was not much to convey a normative content, but to keep track of particular moments within juridical and administrative processes. For private recipients, they served as reminders of memorable events; for administrators and bureaucrats, as reference archival documents. ${ }^{69}$ Their overall poor rate of preservation indicates that, even before the 5th century, other types of legal texts were preferably quoted as authoritative sources by jurists, most notably rescripts. ${ }^{70}$ Records of imperial decreta and interlocutiones seem to have been included in law codes by way of exception, when no alternative ruling of a given emperor was available on a specific point of law.

From the 490s, the complete lack of attestations for this kind of imperial pronouncements can be regarded as sign of the gradual interiorization of the principle of generalitas by bureaucrats and administrators. Though minutes were in all likelihood still produced at court, the fact that they were no longer quoted as general law texts suggests that central imperial archives were in better state, and greater care was taken of safely keeping documents which best met the formal requirements for publication and official dissemination. These criteria were expounded by Valentinian III in the so-called lex citandi (a. 426), which restricted the validity of imperial decisions on appeals and petitions to the particular cases for which they had been issued, unless provisions for wider application were explicitly

67. On the notion of generalitas, RIEDLBERGER 2020, 153-168 and 185-211.

68. Above, 255 and 259.

69. On early imperial commentarii as «aide-memoire» and "archives de reference»: Mourgues 1998, 130-141.

70. See above, 248, and Honoré 1994, 29. 
made. ${ }^{71}$ The later reception and parallel evolution faced by records of imperial judgments and imperial rescripts supports the view that the principle of generalitas shaped not only the way Theodosian and Justinian compilers looked at earlier legislation, but also the production of new normative texts and, more generally, juridical and administrative action.

At about the same time when documentary attestations of imperial decreta and interlocutiones drop in number and finally disappear from our records, the amount of private imperial rescripts also appears to shrink. Until the late 3rd century, imperial rescripts were regarded as authoritative legal precedents and effective means to clarify imperial law. Thousands such pronouncements ascribed to 2nd- and 3rd-century emperors are known. ${ }^{72}$ These texts were extensively collected and constituted the backbone of the Gregorian and the Hermogenian Code, the first collections of imperial laws compiled during the reign of Diocletian. On the contrary, such imperial pronouncements were excluded from the Theodosian Code; the Justinian Code, drawing upon the Gregorian and Hermogenian collections for the period before 313, generally admitted only pre-Costantinian rescripts. From the reign of Constantine onwards, very few private imperial rescripts survive..$^{73}$ Yet, unlike records of imperial oral judgments, rescripts did not completely disappear from our sources. In the 4th and 5th centuries they continued to be engraved on stone with significant frequency $;{ }^{74}$ they were also copied in ecclesiastical collections of documents and Egyptian papyri. But this survival was ensured at the price of important changes in the form of these documents, and in the way they acted as a means of communication between rulers and ruled.

Direct rescripts addressed to individuals and communities are no longer attested after the reign of Constantine. This does not mean they ceased to be issued altogether: indirect references to the individual grant of special privileges in the form of adnotationes can still be found in

71. Cod. Iust. 1.14.2-3; SIRKS 2007, 20-29

72. For the period between 193 and 235, CoRIAT 1997, 115-132, numbers 38 rescripts transmitted by papyri, 21 inscriptions and 1171 texts known through legal sources, particularly the Justinian Code and the Digest. On later jurisprudence: Honoré 1994 and CorCoran 2000, 25-73. On epigraphic evidence: Hauken 1998.

73. For Constantine, a dozen of attestations is transmitted by the Fragmenta Vaticana and (to a lesser extent) the Justinian Code (Corcoran 2000, 301-302), plus two epigraphic texts (MAMA VII 305 and CIL XI 5265). We have six attestations for Valens, from the Consultatio veteris cuiusdam iurisconsulti, one papyrus (P. Lips. 34-35: FeIssel 2004, 45) and two inscriptions (Ephesos Ia 42 and 43). Thereafter, until the time of Justinian, less than ten rescripts are known, mainly through ecclesiastical sources: FeIssel 2004 and ID. 2009.

74. Feissel 2009, particularly 99 and 103. 
5th-century legislation. ${ }^{75}$ However, no copy of such documents survives. What we find in epigraphic and documentary sources are indirect administrative rescripts addressed to state officials. These could deal with problems concerning specific individuals and communities; however, the communication of imperial decisions was filtrated by local institutional intermediaries. Moreover, the text of imperial replies tended to be dissociated from the petition which had elicited it: «nous ne possedons plus, après 451, aucun dossier cumulant petition et rescript. $\gg^{76}$ Under Justinian, the transition towards a "generalized" form of rescript, typically casted in the form of the pragmatic sanction, appears to be completed. Justinian Novels include a number of such administrative rescripts; unlike their earlier counterparts, these are long and articulated texts, overwhelmingly issued in Greek, which incorporated and re-elaborated the content of the requests which had prompted imperial reactions. ${ }^{77}$

\section{Conclusions}

The disappearance of imperial decreta and interlocutiones from the number of preserved sources at the turn of the 5th century and the substantial transformations undergone in the same period by imperial rescripts can be regarded as significant parallel phenomena. As documentary outputs of cognate forms of imperial jurisdiction, these documentary genres were affected by the redefinition of the emperor's role as an arbiter and a source of justice, which impacted on administrative procedures, and by the parallel refinement in the understanding of what general law was, which affected the dissemination and preservation of imperial pronouncements.

The administration of justice was a fundamental facet of the imperial role, and as such could never be easily neglected. However, its actual exercise and advertisement resorted to procedural codes and bureaucratic forms of communication which evolved greatly over time. The changes undergone by the sources we have considered are revealing about how those in power wanted imperial justice to be understood and perceived, and what bureaucratic means they employed to convey such an image to targeted audiences. The described tendency to administrative mediation, formal generalitas and ceremonialization acted as a fundamental factor in reducing both the actual frequency and the documentary visibility of imperial adjudication during late antiquity.

75. MATHISEN 2004.

76. FeISSEL 2004, 40.

77. FeIsSel 2004, 40-44. 
The exclusion of records of proceedings and private individual rescripts from admitted and officially circulated legal texts had an impact on the language and register of imperial legislation, and more generally on imperial official communication. The voice of the empire's master, spread through state-sponsored publication, did not resound in brief and blunt utterances or replies anymore; on the contrary, it expressed itself in long texts and in an elaborated language, aimed at self-justification, persuasion and the building of consensus. In this view, the uses of recorded proceedings within court bureaucracy and in official imperial communication place itself in apparent disagreement with the trends observed in other spheres of institutional and social life during late antiquity. The archival and communicative policies implemented by court bureaucracy seem to voice the distancing, elevation and sacralization of the imperial figure, just as at the procedural level did the multiplication of administrative filters and intermediaries. The development of the imperial ceremonial at the palace and in public venues is usually regarded as the most conspicuous expression of this cultural change. The gradual formalization in minuted records of imperial pronouncements and their final abandonment as accepted sources of imperial law, to the advantage of more elaborated legal documents, can be regarded as a product of the same cultural and political climate.

\section{Bibliography}

ANDRIOLLo, Luisa (2018): «Imperial adlocutiones to the army: performance, recording and functions (2nd - 4th centuries CE)», GFA 21, 67-99.

Barnes, Thimoty D. (1982): The New Empire of Diocletian and Constantine, Cambridge, Mass.-London.

BianchinI, Mariagrazia (1975): «Per l'interpretazione di CI 10.48.2», Labeo 21, 333-342.

Bianchini, Mariagrazia (1984): "L'imperatore Costantino e una certa Agrippina: Riflessioni su CTh 8.15.1", in Giufreè, Vincenzo (ed.), Sodalitas. Scritti in onore di Antonio Guarino, Naples, 1191-1206.

Butr, Ignazio (1982): "La cognitio extra ordinem: da Augusto a Diocleziano", in $A N R W$ II.14, 29-59.

Cameron, Alan (1976): Circus Factions: Blues and Greens at Rome and Byzantium, Oxford.

Castello, Maria G. (2018): "La Collectio Avellana e gli archivi: una questione aperta", in Lizzi Testa, Rita and Marconi, Giulia (eds.), The Collectio Avellana and Its Revivals, Cambridge, 302-317. 
AND PERCEPTIONS IN THE LIGHT OF DOCUMENTARY EVIDENCE

Coles, Revel A. (1966): Reports of Proceedings in Papyri, Brussels.

Connolly, Serena (2010): "Constantine answers the veterans", in McGill, Scott et al. (eds.), From the Tetrarchs to the Theodosians. Later Roman History and Culture, 284-450 CE, Cambridge-New York, 93-114.

Corcoran, Simon (2000): The Empire of the Tetrarchs: Imperial Pronouncements and Government AD 284-324, Oxford.

Corcoran, Simon (2006): "Emperor and Citizen in the Era of Constantine», in Hartley, Elizabeth et al. (eds.), Constantine the Great: York's Roman Emperor, London, 41-51.

Corcoran, Simon (2018): "Less of the same? Continuity and change in the official epigraphy of the late Empire», Travaux et Mémoires 22/2, 3-27.

Coriat, Jean-Pierre (1997): Le prince législateur. La technique législative des Sévères et les méthodes de création du droit impérial à la fin du Principat, Rome.

Coriat, Jean-Pierre (2016): "L'empereur juge et son tribunal à la fin di Principat: Un essai de synthèse», in HaEnsch (2016), 41-61.

Delmaire, Roland (2012): «Du Code Théodosien au Code Justinien. L'adaptation des lois anciennes à des situations nouvelles», in CrogIEZPétrequin, Sylvie and Jaillette, Pierre (eds.), Société, économie, administration dans le Code Théodosien, Villeneuve d'Ascq, 165-182.

Dillon, John N. (2012): The Justice of Constantin. Law, Communication, and Control, Ann Arbor.

DraKe, Harold (2015): "Speaking of Power: Christian Redefinition of the Imperial Role in the Fourth Century», in WIENAND, JohannEs (ed.), Contested Monarchy. Integrating the Roman Empire in the Fourth Century AD (Oxford), 291-308.

DvornIK, Francis (1951): "Emperors, Popes and General Councils", DOP 6, 3-23.

FÄrBER, Roland (2014): Römische Gerichtsorte. Räumliche Dynamiken von Jurisdiktion im Imperium Romanum, Munich.

FeIssel, Denis (2009): «Les actes de l'état impérial dans l'épigraphie tardive (324-610): prolégomènes à un inventaire», in HaEnsch, Rudolf (ed.), Selbstdarstellung und Kommunikation. Die Veröffentlichung staatlicher Urkunden auf Stein und Bronze in der Römischen Welt, Munich, 97-128 [reprinted in FeIssel (2010), 43-68].

Feissel, Denis (2004): «Pétitions aux empereurs et formes du rescrit dans les sources documentaires du $\mathrm{IV}^{\mathrm{e}}$ au VI $\mathrm{VI}^{\mathrm{e}}$ siècle», in FeIssel and Gascou (2004), 33-49 [reprinted in Feissel (2010), 363-384].

FeIssel, Denis (2010): Documentation, droit, diplomatique de l'empire romain tardif, Paris.

Feissel, Denis and Gascou, Jean (eds.) (2004): La pétition à Byzance, Paris. 
Gaudemet, Jean (1979): La formation du droit séculier et du droit de l'Église aux IVe et Ve siècles, $2^{\mathrm{e}}$ édition, Paris.

Graumann, Thomas (2018): "Documents, Acts and Archival Habits in Early Christian Church Councils: A Case Study», in Bausi, Alberto et al. (eds.), Manuscripts and Archives: Comparative Views on Record-Keeping, Berlin-Boston, 273-294.

Haensch, Rudolf (2007): «Apokrimata und Authentica. Dokumente römischer Herrschaft in der Sicht der Untertanen", in HaEnsch, Rudolf and HeInRichs, Johannes (eds.), Herrschen und Verwalten. Der Alltag der römischen Administration in der Hohen Kaiserzeit, Köln, 213-233.

HaEnsCh, Rudolf (2008): "Des empereurs et des gouverneurs débordés. À propos des lettres d'Hadrien aux technites dionysiaques récemment publiées», CCG 19, 177-186.

HaEnsch, Rudolf (ed.) (2016): Recht haben und Recht bekommen im Imperium Romanum. Das Gerichtswesen der Römischen Kaiserzeit und seine dokumentarische Evidenz, Warsaw.

Harries, Jill (1999): Law and Empire in Late Antiquity, Oxford.

Hauken, Tor (1998): Petition and Response; An Epigraphic Study of Petitions to Roman Emperors 181-249, Bergen.

Honoré, Tony (1994): Emperors and Lawyers. Second edition. Completely Revised. With a Palingenesia of Third-Century Imperial Rescripts 193305 A.D., Oxford.

Honoré, Tony (1998): Law in the Crisis of Empire, 379-455 AD. The Theodosian Dynasty and Its Quaestors, Oxford.

HurLet, Frédéric (2016): «Les origines de la juridiction impériale: Imperator Caesar Augustus iudex", in Haensch (2016), 5-39.

Kaygusuz, Ismail (1987): "Neue Inschriften aus Ainos (Enez)», EA 8, 65-70.

Kelly, Christopher (2004): Ruling the Later Roman Empire, Cambridge, Mass. and London.

Kelly, John M. (1957): Princeps iudex. Eine Untersuchung zur Entwicklung und zu den Grundlagen der kaiserlichen Gerichtsbarkeit, Weimar.

Mantovani, Dario (2015): Review of Wankerl (2009), ZRG 132, 654-662.

Mathisen, Ralph W. (2004): "Adnotatio and Petitio: The Emperor's Favor and Special Exceptions in the Early Byzantine Empire», in FeIssel and Gascou (2004), 23-32.

Matthews, John F. (2000): Laying Down the Law. A Study of the Theodosian Code, New Haven-London.

McEvor, Meaghan (2013): Child Emperor Rule in the Late Roman West, AD 367-455, Oxford.

Millar, Fergus (1977): The Emperor in the Roman World (31 BC-AD 337), London. 
Millar, Fergus (2006): A Greek Roman Empire. Power and belief under Theodosius II, 408-450. Berkeley-Los Angeles-London, 2006.

Miller, David J. D. and SARrIs, Peter (2018): The Novels of Justinian. A Complete Annotated English Translation, Cambridge.

Moffatt, Anne and Tall, Maxeme (2012): Constantine Porphyrogennetos. The Book of Ceremonies, Canberra.

Moreno Resano, Esteban (2003): «La acepción de interlocutio en derecho romano», RIDA 50, 249-286.

Moreno Resano, Esteban (2008): «Las 'interlocutiones' imperiales: origen y evolución», Index 36, 461-490.

Mourgues, Jean-Louis (1998): "Forme diplomatique et pratique institutionnelle des commentarii augustorum», in La mémoire perdue. Recherches sur l'administration romaine, Rome, 123-197.

NöRR, Dieter (1983): "Zu einem fast vergessenen Konstitutionentyp: interloqui de plano", in Studi in onore di Cesare Sanfilippo III, Milan, 521543.

Peachin, Michael (1996): Iudex vice Caesaris. Deputy Emperors and the Administration of Justice during the Principate, Stuttgart.

Pergami, Federico (2000): L'appello nella legislazione del tardo impero, Milan.

Riedlberger, Peter (2020): Prolegomena zu den spätantiken Konstitutionen, Stuttgart-Bad Cannstatt.

Rizzi, Mariagrazia (2012): Imperator cognoscens decrevit. Profili e contenuti dell'attività giudiziaria imperiale in età classica, Milan.

Rolfe, John C. (1950): Ammianus Marcellinus. History, Vol. I, Cambridge, MA.

Schamp, Jacques (2006): Jean le Lydien. Des Magistratures de l'état romain. Tome II, Paris.

Schwartz, Eduard (1933-1935): Acta conciliorum oecumenicorum. Tomus alter (6 voll.), Berlin-Lipsia.

Sirks, Adriaan J. B. (2007): The Theodosian Code. A Study, Friedrichsdorf.

STOLTE, Bernard (2003): "Jurisdiction and the representation of power, or the Emperor on circuit», in DE BloIs, Lukas et al. (eds.), The Representation and Perception of Roman Imperial Power, Amsterdam, 261-268.

TeITler, Hans C. (1985): Notarii and exceptores: An Inquiry on the Role and Significance of Shorthand Writers in the Imperial and Ecclesiastical Bureaucracy of the Roman Empire (from the Early Principate to c. 450 $A D)$, Amsterdam.

TuORI, Kaius (2016): The Emperor of Law. The Emergence of Roman Imperial Adjudication. Oxford.

VolterRa, Edoardo (1971): «Il problema del testo nelle costituzioni imperiali», in La critica del testo II, Florence, 821-1097. 
WankerL, Veronika (2009): Appello ad principem. Urteilsstil und Urteilstechnik in kaiserlichen Berufungsentscheidungen (Augustus bis Caracalla), Munich.

Westermann, William L. and Schiller, A. Arthur (eds.), transl. and commentary (1954): Apokrimata. Decisions of Septimius Severus on Legal matters, New York.

Whiтвy, Michael and Whiтвy, Mary (1989): Chronicon Paschale, 284-628 $A D$, Liverpool.

Youtie, Herbert C. and Schiller, A. Arthur (1955): «Second thoughts on the Columbia Apokrimata (P.Col. 123)», CE 30, 327-345. 